\title{
HOW MUCH DO HOUSEHOLDS REALLY LOSE BY CLAIMING SOCIAL SECURITY AT AGE 62?
}

\author{
Wei Sun and Anthony Webb* \\ CRR WP 2009-11 \\ Released: March 2009 \\ Draft Submitted: March 2009 \\ Center for Retirement Research at Boston College \\ Hovey House \\ 140 Commonwealth Avenue \\ Chestnut Hill, MA 02467 \\ Tel: 617-552-1762 Fax: 617-552-0191
}

\begin{abstract}
* Wei Sun is a graduate research assistant with the Center for Retirement Research at Boston College (CRR). Anthony Webb is a research economist at the CRR. The research reported herein was pursuant to a grant from the U.S. Social Security Administration (SSA) funded as part of the Retirement Research Consortium (RRC). The findings and conclusions expressed are solely those of the authors and do not represent the views of SSA, any agency of the Federal Government, the RRC, or Boston College. The authors would like to thank Alicia Munnell for helpful comments.
\end{abstract}

(C) 2008, by Wei Sun and Anthony Webb. All rights reserved. Short sections of text, not to exceed two paragraphs, may be quoted without explicit permission provided that full credit, including (C) notice, is given to the source. 


\title{
About the Center for Retirement Research
}

The Center for Retirement Research at Boston College, part of a consortium that includes parallel centers at the University of Michigan and the National Bureau of Economic Research, was established in 1998 through a grant from the Social Security

Administration. The Center's mission is to produce first-class research and forge a strong link between the academic community and decision makers in the public and private sectors around an issue of critical importance to the nation's future. To achieve this mission, the Center sponsors a wide variety of research projects, transmits new findings to a broad audience, trains new scholars, and broadens access to valuable data sources.

\author{
Center for Retirement Research at Boston College \\ Hovey House \\ 140 Commonwealth Avenue \\ Chestnut Hill, MA 02467 \\ phone: 617-552-1762 fax: 617-552-0191 \\ e-mail: crr@bc.edu \\ www.bc.edu/crr
}

\author{
Affiliated Institutions: \\ The Brookings Institution \\ Massachusetts Institute of Technology \\ Syracuse University \\ Urban Institute
}




\begin{abstract}
Individuals can claim Social Security at any age from 62 to 70 although most claim at 62 or soon thereafter. Those who delay claiming receive increases that are approximately actuarially fair. We show that expected present value calculations substantially understate both the optimal claim age and the losses resulting from early claiming because they ignore the value of the additional longevity insurance acquired as a result of delay. Using numerical optimization techniques, we illustrate that for plausible preference parameters, the optimal age for non-liquidity constrained single individuals and married men to claim benefit is between 67 and 70. We calculate that Social Security Equivalent Income, the amount by which benefits payable at sub-optimal ages must be increased so that a household is indifferent between claiming at those ages and the optimal combination of ages, can be as high as 19.0 percent.
\end{abstract}




\section{Introduction}

In the United States, most aged workers receive retirement benefits from Social Security. Benefits are paid in the form of an inflation-protected annuity. Individuals can claim benefits at any age from 62 to 70 . There is no requirement that benefits be claimed immediately on retirement, although the benefits of those who continue to work between 62 and Full Retirement Age (FRA) are subject to an earnings test. Those who postpone claiming until age 70 receive 76 percent more per month than those who claim at age 62 . The increases are approximately actuarially fair and Sass et al (2007) show that the expected present value of benefits varies little with claiming age.

But choosing a claiming age is not simply a matter of maximizing the expected present value of lifetime benefits. Individuals who delay claiming also acquire additional longevity insurance. They can be thought of as returning this month's check to the Social Security Administration in return for additional annuity income. Previous research (Mitchell et al 1999) has shown that annuities have a value very considerably in excess of their money's worth, the expected present value, divided by the premium paid, because they provide the purchaser with valuable insurance against the risk of outliving their wealth.

Most individuals claim benefits at age 62 or soon thereafter (Muldoon and Kopcke, 2008). We show that most households claim early as a matter of choice in the sense that they have sufficient financial wealth to delay claiming after retirement, often for substantial periods.

Using numerical optimization techniques, we calculate the optimal ages at which husbands and wives in various household types should claim benefits, taking account of the additional longevity insurance purchased as a result of delay. We show that the optimal age at which single individuals and married men should claim benefits is between 67 and 70, four to seven years later than the current average claim age, a result that is robust to alternative assumptions regarding level of risk aversion, relative mortality risk, and rate of time preference. 
We calculate Social Security Equivalent Income, the factor by which the Social Security benefits of a non-liquidity constrained retired household claiming at sub-optimal ages must be increased so that it is as well-off in expected utility terms as at the optimal combination of ages. ${ }^{1}$ In contrast to the money's worth calculations of previous research, we show that households incur substantial losses as a result of early claiming. For example, assuming a coefficient of risk-aversion of five and a three percent real interest rate and rate of time preference, a single-earner married couple in which the husband is three years younger than the wife would require a 15.9 percent increase in the benefits payable if they both claimed at age 62 to be as well off as at the optimal claim ages of 69 for the husband and 66 for the wife.

The remainder of the paper is organized as follows. Section 1 outlines relevant features of the Social Security program. Section 2 discusses previous research on the Social Security claiming and annuitization decisions. Section 3 presents our model of the claiming decision. Section 4 presents our results and Section 5 concludes.

\section{The Social Security program}

Social Security provides three categories of retirement benefits, retired worker, spousal, and survivor benefit. Individuals can claim retired worker benefits at any age from 62 to 70. The Full Retirement Age for those born between 1943 and 1954 is 66. The benefits of individuals claiming before that age are actuarially reduced, by 25 percent for those claiming at age 62 . The benefits of those claiming late are actuarially increased, by 32 percent for those claiming at 70 .

\footnotetext{
${ }^{1}$ In all our analyses, we abstract from the labor supply decision. Most individuals permanently leave the labor force well before the ages at which we calculate it is optimal to claim Social Security benefits. Working individuals who have not attained the Full Retirement Age are subject to the Social Security Earnings Test. Their benefits are reduced or withdrawn, but they are compensated with increased benefits after they retire, using the formula applied to individuals who delay claiming. But as Benitez-Silva and Heiland (2008) point out, the increase in benefit only takes effect from the date at which the individual attains his Full Retirement Age, so that an individual who first claims and then, for a period ending prior to his Full Retirement Age, earns an amount sufficient to eliminate his benefits, is worse off than an individual who simply delays claiming until he has ceased working.
} 
The reductions and increases for retired workers are approximately actuarially fair in the sense that the expected present value (EPV) of Social Security benefits, discounted by a three percent real rate of interest and annual survival probabilities, varies little with the age of claiming. ${ }^{2}$ But this misses the impact of the claiming age on Social Security survivor and spousal benefits.

Spouses of retired workers can claim a spousal benefit, if that exceeds their own retired worker benefit, provided they have turned 62 and their spouse has already claimed his benefit. At the spouse's Full Retirement Age, they are entitled to a benefit of one half of their husband's Primary Insurance Amount, or PIA, (the benefit the husband could receive if he claims at his Full Retirement Age). The benefits of spouses claiming early are actuarially reduced, by as much as 30 percent for those claiming at age 62 . The spousal benefit does not increase if claiming is delayed beyond the Full Retirement Age.

Most wives have lower lifetime earnings than their husbands, and will therefore qualify for survivor benefits on their husband's death. ${ }^{3}$ Survivor benefits can be claimed as early as age 60. For women born between 1945 and 1956, this benefit equals 100 percent of their husband's benefit if he dies when she is 66 or older, subject to a floor of 82.5 percent of his Primary Insurance Amount. If her husband dies before she attains age 66, her benefit is subject to an actuarial reduction of as much as 28.5 percent, but is subject to a floor of 71.5 percent of her husband's Primary Insurance Amount. Most women outlive their husbands, often by a considerable margin, but are usually considerably older than 66 when their husband dies. A husband who delays claiming from age 62 to 70 therefore usually increases the annual amount of his widow's survivor benefit by 60 percent. ${ }^{4}$ So, delay significantly increases the present value of the total of the retired worker and survivor benefits payable over his and his wife's joint lifetime, even though it has only a

\footnotetext{
${ }^{2}$ The Social Security Administration uses a three percent real interest rate when making their actuarial assumptions, although the yield on long-dated TIPS has been below three percent since 2002 .

${ }^{3}$ Men are also eligible for survivor benefits if they exceed their own retired worker benefit. But most survivor benefits are paid to women.

${ }^{4}$ A surviving spouse claiming survivor benefit after her FRA would receive a benefit of 132 percent of her husband's PIA, if he had delayed claiming until age 70. In contrast, she would receive only 82.5 percent if he had claimed at age 62 .
} 
small impact on the present value of the retired worker benefit payable during his lifetime.

As the amount of the survivor benefit is based on the husband's, not the wife's claim age, a married woman who delays claiming can expect to receive an increased retired worker or spousal benefit not for her lifetime, but for the shorter period ending on her husband's death. ${ }^{5}$ This reduces the advantage of delay and means that it is optimal for married women to claim benefits at younger ages than otherwise identical single women. But a spousal benefit can only be claimed once the husband has claimed his retired worker benefit. Although early claiming of the retired worker benefit will often facilitate early claiming of the spousal benefit, thereby increasing its present value, it will also, for the reasons explained in the previous paragraph, reduce the value of the wife's survivor benefit. ${ }^{6}$

The option to delay claiming is also an option to purchase an annuity. ${ }^{7}$ To illustrate, a single individual with a PIA of $\$ 1,000$ can claim a retired worker benefit of $\$ 750$ a month at age 62. If he delays until age 63 , his benefit increases to $\$ 800$ a month. He is in effect

\footnotetext{
${ }^{5}$ Women are not required to claim survivor benefit immediately on their husband's death. Our programs assume that women delay claiming until the optimal age. But the amount of a woman's survivor benefit does not increase after she has attained her Full Retirement Age, so this rule only affects the small minority of women who are widowed before attaining that age.

${ }^{6}$ We ignore three unusual, but allowable, strategies for claiming Social Security benefits that may allow some households to receive increased benefits but appear to be little-used, namely 1) claiming Social Security benefits at, say, age 62 and then reclaiming at, say, age 66 at a higher benefit level, as long as they pays back past benefits without interest, essentially taking an interest-free loan from the Social Security Administration, 2) claiming spousal benefit at the Full Retirement Age and switching to retired worker benefit at a later date, and 3) upon reaching the Full Retirement Age, claiming Social Security benefit, and then suspending payment, thereby enabling the individual's spouse to claim a spousal benefit. These strategies are discussed on the Center for Retirement Research website at http://crr.bc.edu/images/stories/uniqueclaiming.pdf.

${ }^{7}$ The terms are generally more favorable than those obtainable from commercial insurers, sometimes by substantial margins. It is difficult to make comparisons because commercial annuities provide annuities with fixed survivor benefits whereas the increment to Social Security survivor benefit depends on the ages of both claim and spouse's death. To illustrate, assuming a husband's PIA of $\$ 1,000$, a single earner married couple that delays from age 62 to 63 gives up $\$ 750$ plus $\$ 350$, a total of $\$ 1,100$, in return for an additional benefits of $\$ 50$ and $\$ 25.00$, a total of $\$ 75.00$, a yield of 6.8 percent. As of 18 February 2009 , a leading provider of inflation protected annuities quoted a yield of 5.4 percent for a joint life and two thirds survivor annuity payable monthly in advance with no guarantees. At age 63, the corresponding yields are 9.3 percent for the Social Security annuity, and 5.5 percent for the commercial annuity. But at age 69 , the rankings are reversed with the Social Security annuity yielding 4.6 percent and the commercial annuity 6.5 percent, reflecting the fact that the spousal benefit no longer increases after the Full Retirement Age.
} 
buying an annuity of $\$ 50$ a month ( $\$ 800$ minus $\$ 750$ ) at a cost of $\$ 9,000$ ( $\$ 750$ times twelve months, the year's benefits foregone). A single earner husband and wife who are both the same age and with the same PIA can claim retired worker and spousal benefit of $\$ 750$ and $\$ 350$ at age 62 , a total of $\$ 1,100$. If they delay claiming until age 63 , their Social Security benefits increase by a total of $\$ 75$, to $\$ 800$ and $\$ 375$. They are in effect buying a $\$ 75$ a month joint life and two third survivor annuity (the increase in benefits) for a premium of $\$ 13,200$ ( $\$ 1,100$ times twelve month, the year's benefits foregone).

\section{Previous Research}

Munnell and Soto (2005) calculate the combinations of claim ages that maximize the expected present value of Social Security benefits for married men born in 1948 and their spouses of various ages. They assume population mortality and a three percent real interest rate. They show that the expected present value maximizing combination of ages depend on the age difference between husband and wife and the wife's PIA as a percentage of the husband's.

Table 1 reproduces their key results. Although a wife who is entitled to retired worker benefit based on her own contributions can claim retired worker benefit as soon as she turns 62 , regardless of whether her husband has claimed his retired worker benefit, this may not be a good strategy if her spousal benefit exceeds her retired worker benefit. The age at which she claims her retired worker benefit determines the early claiming reduction that will apply to her spousal benefit, which becomes payable once her husband claims his retired worker benefit. The additional retired worker benefit received may be insufficient to compensate for the reduction in the spousal benefit.

If the wife's PIA is more than 40 percent of that of her husband, the wife should claim at age 62 and the husband at age 69 , regardless of the age difference. The intuition behind this result is that once the woman reaches some moderate level of retired worker benefits, she maximizes the lifetime value of this component by claiming early because she receives these benefits over the relatively short lifetime of her husband. But her husband 
claims benefits relatively late in order to maximize the value of his wife's survivor benefits.

If the wife's PIA is zero, the wife cannot claim before her husband. Both husband and wife claim at the same time, with the household equating the increment to the expected present value of the survivor benefit resulting from delay with the reduction in the value of the spousal and retired worker benefit. The wife claims later and the husband earlier than when the wife's PIA is more substantial.

Sass et al (2007) extended the above analysis by calculating how much households lost in money's worth terms by claiming at sub-optimal combinations of ages. Using Health and Retirement Study (HRS) data, they calculated that the average loss resulting from both husband and wife claiming as soon as possible at 62 , rather than delaying to the combination of ages that maximized the household's expected present value of benefits was just $\$ 14,135$ (in 2006 dollars), four percent of the maximum value. However, they found that these generally small losses in the present value of total household benefits hid substantial survivor benefit losses.

The above money's worth calculations ignore the longevity insurance value of Social Security. As we will show in Section 4, calculations that ignore the value of the longevity insurance provided by Social Security substantially understate both the optimal age and the cost of early claiming.

The only previous paper that calculates optimal claim ages taking account of the longevity insurance provided by Social Security is Coile et al (2002). But their paper only reported results for single males, and therefore failed to capture the effects of both longevity risk sharing within marriage, and the complex interactions between retired worker, spousal, and survivor benefits discussed in Section 1. They compared the claim age at which a single male would maximize the expected present value of benefits with the expected utility maximizing age. At a three percent interest rate, and assuming population mortality for the 1930 birth cohort, the expected present value of benefits is 
maximized at just 62 years and ten months. ${ }^{8}$ Assuming log utility the utility maximizing age varies from 62 years and eleven months to 65 years, depending on the household's wealth level. ${ }^{9}$

Coile et al (2002), Hurd et al (2004), and Sass et al (2007) analyze claiming behavior. ${ }^{10}$ A problem common to all these studies is that it is difficult to identify the determinants of claiming behavior when the overwhelming majority of individuals claim as soon as they are eligible, or shortly thereafter. Both Coile et al (2002), and Hurd et al (2004) find some evidence that subjective mortality beliefs have an effect. Sass et al (2007) find that having college level education is associated with somewhat later claiming, but find no evidence that the balance of financial decision-making power in the household contributes to early claiming.

Brown et al (2007) analyze the self-reported willingness of HRS individuals aged 50 to 64 to exchange half of their Social Security benefits for an actuarially fair lump sum. Those who chose the lump sum were then asked how they would choose if the lump sum were reduced by 25 percent. Those who chose full benefits were asked how they would choose if the lump sum were increased by 25 percent. Most individuals preferred the lump sum, and 37 percent even preferred the reduced lump sum. They found that health status had some effect on preferences, but that many of the factors that economic theory predicts should have an effect - risk aversion, gender, marital status, wealth, having a pension plan, and children - had no statistically significant effect.

\footnotetext{
${ }^{8}$ The percentage return to delay from age 62 to 63 was substantially higher for the 1930 than for the 1946 birth cohort, making it optimal for men in that cohort to delay beyond age 62, even though they had higher mortality rates than the 1946 cohort.

${ }^{9}$ Under constant relative risk aversion, the marginal value of annuitization depends on the proportion of wealth that is already annuitized. Households with very little financial wealth are already highly annuitized and therefore place relatively little value on further annuity purchases. Log utility implies a considerably higher degree of willingness to substitute intertemporally than is typically assumed in models of retirement wealth decumulation. The delayed retirement credit beyond the 1930 birth cohort Full Retirement Age of 65 was only three percent, making delay beyond that age unattractive even to those placing a high value on further annuitization.

${ }^{10}$ There are also models, for example, Gustman and Steinmeier (2002) that do not separate the claiming from the retirement decision.
} 
Previous research has reached similar conclusions. Warner and Pleeter (2001) analyzed how service personnel participating in a downsizing program chose between a lump sum and a lifetime pension. The decisions of some individuals were consistent with discount rates exceeding 17 percent, although in contrast to Brown et al, Warner and Pleeter (2001) found that decisions varied with education, race, gender, number of dependents, and cognitive ability.

Hurd and McGarry $(1995,2002)$ showed that individuals appear to have reasonable subjective mortality beliefs, so it seems unlikely that the above findings reflect systematic biases in forecasting life expectancy. Although some households may have high rates of time preference or be subject to binding liquidity constraints, most households entering retirement have accumulated non-trivial amounts of financial wealth, behavior that would often, but not invariably be inconsistent with a high discount rate.

Another explanation for the prevalence of early claiming is proposed by Benitez-Silva et al (2007). They show that a belief that there is even a small probability that the government will reduce Social Security benefits can result in households pre-empting the government and claiming benefits at the earliest permissible age.

The low value placed on the Social Security annuity is another manifestation of individuals' well-documented reluctance to annuitize. Brown (2007) contains a review of possible explanations, in addition to the ones discussed in the previous paragraphs.

\section{Modeling the Social Security Claiming Decision}

We follow previous research (Brown and Poterba, 2000, Dushi and Webb, 2004), and assume that couples have a utility function of the following form:

$$
U_{m}\left(C_{t}^{m}, C_{t}^{f}\right)=\frac{\left(C_{t}^{m}+\lambda C_{t}^{f}\right)^{1-\gamma}}{1-\gamma}, U_{f}\left(C_{t}^{f}, C_{t}^{m}\right)=\frac{\left(C_{t}^{f}+\lambda C_{t}^{m}\right)^{1-\gamma}}{1-\gamma}
$$

where $\lambda$ measures the jointness of consumption, $C_{t}^{m}, C_{t}^{f}$ denote the consumption of the husband and wife at time $t$, and $\gamma$ is the coefficient of risk aversion. When $\lambda$ equals one, 
all consumption is joint. When $\lambda$ equals zero, none of the household's consumption is joint. We assume that $\lambda$ equals 0.5 .

In our base case, we endow households with an amount of financial wealth at age 62 that is equal to the expected present value of the Social Security benefits they would receive if they both claimed at age 62. ${ }^{11}$ This amount of financial wealth is sufficient to ensure that households have sufficient financial assets to fund consumption from age 62 to 70 of an amount equal to their benefits payable at age 70 .

Each period, the husband and wife each decide whether to claim Social Security benefits, and what percentage of unannuitized wealth to consume. ${ }^{12}$ The optimal choices are permitted to depend on financial wealth and whether both or only one of the spouses is alive. The problem is solved using dynamic programming. ${ }^{13}$

Having determined the optimal combination of claim ages, we then calculate Social Security Equivalent Income (SSEI), the factor by which the benefits payable at other combinations of claim ages must be multiplied so that household is indifferent between claiming at the optimal combination of ages, and claiming at that other combination. By construction, SSEI equals one at the optimal combination of claim ages. At sub-optimal combinations of claim ages, SSEI is greater than one. A household claiming at a suboptimal age would require its Social Security benefits to be multiplied by the factor shown in the relevant cell in the table to be indifferent between claiming at the suboptimal and the optimal ages.

\footnotetext{
${ }^{11}$ Using population mortality tables for the 1946 cohort.

${ }^{12} \mathrm{We}$ assume that households do not adopt any of the seldom-used claiming strategies described in the Center for Retirement Research publication "Strange, but True: Unusual Strategies for Claiming Social Security Benefits." http://crr.bc.edu/linked_in_content_pages/unique_claiming_strategies.html

${ }^{13}$ This involves calculating an optimal strategy in period $T$, assumed to be age 100 , calculating the utility of that strategy, and working back to age 62 , calculating the strategy in each preceding period under the assumption that the household adopts the optimal strategy from that period onwards. The optimal strategy for each period is calculated for all feasible wealth values and all feasible Social Security retired worker, spousal, and survivor benefits.
} 
We consider single men, single women, and married couples. Our base case is a oneearner couple, both the same age, with population mortality for the 1946 birth cohort. Following previous research, we assume they have a three percent interest rate that also equals the rate of time preference.

On average, there is a three year age difference between husbands and wives in HRS households, and in view of the impact of age difference on the value of both spousal and survivor benefits, we consider alternatives in which the wife is one to six years younger than the husband, and has population mortality for the 1947 to 1952 birth cohort, as appropriate. ${ }^{14}$ We also consider couples in which the wife is entitled to her own retired worker benefit.

Warner and Pleeter (2001) provide evidence that some households may have quite high rates of time preference, and we therefore consider alternative rates of time preference of five and ten percent. We also consider alternatives in which the husband and wife have the average mortality rates of high and low mortality socio-economic groups.

The current rate of interest on Treasury Inflation Protected Securities is considerably less than three percent. Households can, of course, obtain a higher expected return than three percent by investing in risky equities. But households are rarely at a corner solution where the size of their equity portfolio is constrained by their financial wealth. Coile and Milligan (2006) show that most retired households hold a considerable proportion of their wealth in cash and short-term deposits where both anticipated and historic real returns have fallen well short of three percent and which could be drawn down were the household to delay claiming Social Security. So our assumed rate of interest biases our results against delay.

\footnotetext{
${ }^{14}$ In these alternatives, we calculate the present value of age 62 benefits discounted back to when the husband is aged 62 .
} 
Our analysis ignores income tax. Social Security benefits receive favorable tax treatment, and Mahaney and Carlson (2007) show that taxation magnifies the advantages of delayed claiming of Social Security. ${ }^{15}$

\section{Results}

Table 2 reports SSEI for single men and women. The first and fourth columns show SSEI where the utility of consumption is the dollar amount of that consumption, and the individual's objective is simply to maximize the money's worth of his Social Security benefits. The remaining columns show SSEI assuming CRRA utility at coefficients of risk aversion of two and five. ${ }^{16}$ A single male maximizes the money's worth of his benefits if he claims at age 62 . But he would only be slightly worse off claiming at other ages. For example, if he delayed claiming until age 66, his Full Retirement Age, he would require a 1.2 percent increase in his benefits to be as well off as at the optimal claim age of 62 . In contrast, at a coefficient of risk aversion of five, the expected utility of benefits is maximized at age 69. A single male claiming at age 62 would require a 15.8 percent increase in benefits to be as well off in expected utility terms as he would be were he to delay until age 69 , reflecting the high value placed on the additional longevity insurance acquired as a result of delay.

Single women, maximize the money's worth and expected utility of benefits at 67 and 70 respectively. A single woman claiming at age 62 would require only a 2.9 percent increase in benefits to be as well of as at the optimal age. But at a coefficient of risk aversion of five, the required increases in benefits 19.0 percent.

\footnotetext{
${ }^{15}$ The taxation treatment of Social Security benefits is as follows. First, the household's "combined income" is calculated. This equals regular taxable income plus 50 percent of Social Security income. The amount of Social Security income that is taxable is the minimum of three tests: 1) 50 percent of combined income over the first threshold ( $\$ 25,000$ for singles and $\$ 32,000$ for married couples), plus 35 percent of combined income over the second threshold ( $\$ 34,000$ for singles and $\$ 44,000$ for married couples). 2) 50 percent of benefits plus 85 percent of combined income over the second threshold. 3) 85 percent of benefits. A household that substitutes a dollar of regular income (for example, an IRA withdrawal) for a dollar of Social Security income reduces its combined income by 50 cents. This will in turn reduce the amount of Social Security income that is taxable. For example, if rule (3) applies, taxable Social Security income will decrease by 42.5 cents. Adjusted Gross Income will decrease by $\$ 1.425$, and a household in the 25 percent tax bracket will save just over $\$ 0.35$ in federal taxes.

${ }^{16}$ These figure rest in the middle of the range reported in the literature, which tends to cluster between 2 and 10 depending in part on whether the estimates are derived from portfolio theory, purchases of insurance, economic experiments, or preferences over lotteries (Chetty 2003).
} 
The cost of early claiming is greater at higher degrees of risk-aversion, reflecting the greater value that the risk-averse place on the opportunity to acquire additional longevity insurance. But the optimal age varies little with the individual's degree of risk-aversion, and it is optimal for even relatively risk-tolerant individuals to delay claiming until after the Full Retirement Age.

Figure 1 shows the optimal consumption paths for single men claiming at ages $62,66,69$ (the expected utility maximizing age) and 70, assuming a PIA of $\$ 1,000$, a coefficient of risk-aversion of five and an amount of unannuitized wealth that equals the present value of Social Security benefits if those benefits are claimed at age 62. The initial monthly consumption of a single man who claims at 62 is $\$ 1,390$, made up of $\$ 750$ Social Security benefits and $\$ 640$ drawings from unannuitized wealth. Total consumption declines with age. By age 97, unannuitized wealth is totally exhausted, and consumption equals the $\$ 750$ a month Social Security benefits. A man who claims at the expected utility maximizing age of 69 enjoys initial consumption at age 62 of $\$ 1,484$, declining to $\$ 1,240$ by age 88 when unannuitized wealth is exhausted. Importantly, the strategy of claiming at age 69 yields not only the highest consumption at all ages up to 80 but also very much higher consumption at older ages than the strategy of claiming at age 62 .

Table 3 reports SSEI for the base case couple. The first panel shows SSEI where the utility of consumption is simply the dollar amount of that consumption and the household's objective is to maximize the money's worth of benefits. The second and third panels report Social Security Equivalent Income calculations, assuming CRRA utility with coefficients of risk aversion of two and five respectively. We do not report values for infeasible combinations of claim ages - those in which the wife's claim age is less than that of her husband.

The money's worth of benefits is maximized when both husband and wife claim at 66 . But they lose little by claiming at $62-2.7$ percent of age 66 pension wealth. When the coefficient of risk aversion equals two, it is optimal for both to claim at 67 , and a husband 
and wife claiming at age 62 would require an 7.8 percent increase in benefits to be as well off in expected utility terms. When the coefficient of risk aversion equals five, it is optimal for both to claim at 68, and the required increase in benefits 11.1 percent. The combination of ages that maximizes the household's expected utility is almost identical to that which maximizes money's worth. But the money's worth calculations understate the cost of early claiming by as much as 8.4 percentage points.

Figure 2 shows the consumption path of a single earner couple in which the husband and wife both claim at 62, 66, 68 (the optimal age) and 70, assuming a coefficient of riskaversion of five and that they are both the same age. If they both claim at age 62 , their initial monthly consumption is $\$ 2,131$, made up of $\$ 1,100$ Social Security benefits and $\$ 1,021$ drawings from unannuitized wealth. The couple never completely exhausts its unannuitized wealth, although by age 100, total consumption has fallen by almost exactly half to $\$ 1,124$. But if they claim at the optimal age of 68 , their initial consumption at age 62 is $\$ 2,232$, decreasing to $\$ 1,660$ by age 97 , when financial wealth is exhausted. A couple that delays until age 68 enjoys higher consumption in all periods than one that claims at age 62 , and substantially higher consumption at advanced ages.

Table 4 reports SSEI for cases in which the husband is one to six years older than the wife, assuming a coefficient of risk aversion of five, with the base case of a couple who are both the same age shown for comparison. We again do not report infeasible combinations of claim ages. An increase in the age difference increases the value of the wife's survivor benefit because it increases the number of years she is expected to outlive her husband. But it conversely decreases the cost of delay by the husband in claiming his retired worker benefit because delay has less of an impact on the value of the wife's spousal benefit. If the husband is $t$ years older that the wife, then delay by the husband from 62 to $62+t$ can never result in any loss of spousal benefit.

As the age difference increases it becomes optimal for the husband to claim at older ages, and for the wife to claim at younger ages. The husband and wife should claim at the same time if the age difference is four years or less. If the age difference is greater than 
four years, the husband should delay until age 70, and the wife should claim at age 66, her Full Retirement Age. As the age difference increases, so does the cost associated with claiming at age 62 . There is also an increase in the cost associated with the couple claiming at age 62. If the husband is three years older than the wife, the average for this birth cohort, SSEI equals 1.159 and the household would require a 15.9 percent increase in benefits to be as well off in expected utility terms claiming at age 62 as they would be were they to delay until the optimal ages.

Table 5 reports SSEI for two earner households in which the wife's PIA is 25 or 50 percent of that of her husband, with the base case of a single earner couple again shown for comparison. We consider a coefficient of risk aversion of five, and assume that husband and wife are the same age. In the single-earner case, delay by the husband in claiming his retired worker benefit can prevent the wife from claiming her spousal benefit. But as explained in Section 2, if the wife is entitled to her own retired worker benefit, she can claim that benefit at any time after attaining age 62 , switching to spousal benefit, if greater, when her husband claims his retired worker benefit.

As the wife's PIA increases relative to that of her husband, it becomes optimal for the husband to further delay claiming from 68 to 70 . It also becomes optimal for the wife to claim at younger ages. When her PIA is 25 percent of her husband's, it is optimal for her to claim at age 66 , three years before her husband. When it is 50 percent of her husband's, it is optimal for her to claim at age 65 , five years before her husband.

Table 6 reports SSEI for less patient households and those whose mortality differs from the population average, again with our base case shown for comparison. In each case, we consider a single-earner couple in which the wife is the same age as her husband, and assume a coefficient of risk aversion of five.

We first consider impatient households with population average mortality, assuming a five percent rate of time preference in panel two and a ten percent rate in panel three. At higher discount rates, the household places greater weight on consumption early in 
retirement, and it becomes optimal for the husband to claim retired worker benefits at younger ages. But the effect is very small, reflecting the fact that even impatient households plan to consume an amount at least equal to their Social Security benefits until quite late in retirement. Even at an extreme ten percent rate of time preference, it is still optimal for the husband and wife to delay claiming until age 67.

The remaining panels show Social Security Equivalent Income for couples in high and low mortality socio-economic groups, assuming a three percent discount rate. Our low mortality couple is one in which both husband and wife are white and have completed four or more years' college. Our high mortality couple is one in which both husband and wife are black, and have not completed high school. We assume that these couples have the same proportion of unannuitized wealth as our base case couple. ${ }^{17}$ In reality, the average high mortality couple has much smaller proportions of pre-annuitized wealth and would encounter liquidity constraints in the event of delayed claiming. But our calculations serve the broader objective of quantifying the effect on optimal claim ages of plausible variations in subjective mortality beliefs.

We assume that both husband and wife are from the same socio-economic group, and that they both have the average mortality rate for individuals in that group. We calculate group-specific mortality rates by multiplying male and female mortality rates for the 1946 birth cohort by the relative mortality factors reported in Brown et al (2002). The calculation of the factors is explained in detail in that paper. To summarize, the authors estimated a nonlinear model for age-specific mortality for each group, using data from the National Longitudinal Mortality Survey (NLMS), a dataset covering the period 1979 to $1989 .{ }^{18}$ They report relative mortality rates for white men and women with less than a

\footnotetext{
${ }^{17}$ Under our assumption of constant relative risk aversion it is the proportion of wealth that is held in unannuitized form, rather than the absolute amount of that wealth, that determines the optimal claim age and SSEI.

${ }^{18}$ Brown (2002) contains a review of previous literature on socio-economic differences in mortality rates. As Brown et al (2002) point out, the NLMS dataset does not contain mortality data above age 84 . The relative mortality factors at age 85 and up therefore depend not only on the functional form of the mortality model, but also on possibly noisy measures of mortality rates at slightly younger ages. The construction of cohort mortality tables for socio-economic groups is based on the strong assumption that the relative mortality rates of these groups has and will remain constant, even as the relative sizes of the groups change.
} 
high school education, high school or some college, and four years or more college. Blacks are categorized into two educational groups, depending on whether they completed high school. There are insufficient Hispanics in the sample to permit categorization by education. Up to age 87 , the less well educated and minorities have higher mortality. ${ }^{19}$ But this relationship breaks down at older ages. ${ }^{20}$ In results that are not reported, we find that our results are not significantly affected if we assume that age 87 relative mortality rates continue to apply at older ages.

We report SSEI for college-educated whites and blacks with less than a high school education. Socio-economic differences in mortality rates have no effect on optimal claiming ages. A black couple with less than a high school education should delay claiming until age 68 , exactly the same age as a white college-educated couple. Social Security equivalent income varies with socio-economic status, but not by large amounts. For the population as a whole, Social Security equivalent income equals 1.111 if the husband and wife both claim at 62 , in other words, they would require a 11.1 percent increase in benefits to be as well of in expected utility terms claiming at age 62 as at the optimal age. The corresponding values are 1.098 for black couples with less than a high school education and 1.115 for while college educated couples.

Figure 3 shows optimal consumption for the black couple. As in the base case, claiming at the optimal age of 68 yields higher consumption at all ages than claiming at age 62 . Initial consumption at age 62 is three percent higher than in the base case

\section{Conclusion}

Some households have little choice but to both retire early and claim benefits immediately on retirement. They are forced out of the labor market by ill health or lack of job opportunities, and lack the liquid financial wealth to separate the retirement from the claiming decision. But many households have sufficient financial resources to delay

\footnotetext{
${ }^{19}$ The exception is Hispanics who have lower mortality at younger ages. The Hispanic data may reflect survivor bias at older ages.

${ }^{20}$ This might be a real phenomenon, or may reflect measurement error. If there is an upper limit to life expectancy, then there must be some age at which relative mortality rate of the high mortality group falls below that of three low mortality group.
} 
claiming. We calculate that 40 percent of the married couples in the Health and Retirement Study who turned 62 between 1992 and 2006 had sufficient financial assets to fund consumption from age 62 to 68 and 46 percent had sufficient to delay from 62 to $66^{21}$

Our results indicate that these households would be substantially better-off delaying claiming Social Security benefits. The fact that they choose not to is another manifestation of the so-called "annuity puzzle," the well-documented reluctance of retired households to annuitize their financial wealth. Delayed claiming would also likely be effective in reducing the relatively high poverty rate among elderly widows because it would increase their Social Security survivor benefit, which is often their sole or principal source of income.

The optimal policy response may depend on why households appear reluctant to exchange financial for Social Security wealth. If they are practicing mental accounting, and not viewing the two forms of wealth as fungible, or if they are framing delayed claiming as a risky gamble they will lose if they die young, rather than as the purchase of valuable longevity insurance, then the appropriate response may be financial education. ${ }^{22}$ If husbands are attaching insufficient weight to impact of delay on the value of their wife's survivor benefit, then one response might be to require spousal consent to early claiming. ${ }^{23}$ If households are simply following social norms, then setting appropriate defaults might influence behavior. ${ }^{24}$ But a reluctance to decumulate financial assets may also be prompted by a demand for liquidity in the presence of uncertain health care costs. This line of research is at an early stage. DeNardi et al have argued that uncertainty over

\footnotetext{
${ }^{21}$ The Health and Retirement Study is a panel of over 7,000 households containing an individual born between 1931 and 1941 who were interviewed every two years from 1992. Younger birth cohorts were added in 1998 and 2004. We define financial assets as including non-pension financial assets, plus IRAs. A household is classified as having sufficient financial assets to delay claiming from age 62 to age $62+k$ if its financial assets at age 62 are sufficient to fund consumption to time $62+k$ of an amount equal to the Social Security benefits payable at time $62+k$, assuming a three percent real rate of return.

${ }^{22}$ Agnew et al (2008) provides evidence for framing effects.

${ }^{23}$ With a symmetrical requirement placed on wives, although the objective is primarily to affect the husband's behavior.

${ }^{24}$ Mitchell and Utkus (2004) have shown that defaults have a strong impact on participation in and the level of contributions to $401(\mathrm{k})$ plans.
} 
medical expenses may explain why wealthy retired households decumulate their wealth relatively slowly. But it is less clear what effect it does or should have on the value of annuitization. $^{25}$

${ }^{25}$ See Pang and Warshawsky (2008). Turra and Mitchell (2004), and Yogo (2008). 


\section{References}

Agnew, J.R., Anderson L.R., Gerlach J.R., and Szykman L.R. 2008. "Who Chooses Annuities? An Experimental Investigation of the Role of Gender, Framing, and Defaults." American Economic Review: Papers and Proceedings 98(2) :418-422.

Benitez-Silva, H and Heiland, F. 2008. "Early Claiming of Social Security Benefits and Labor Supply Behavior of Older Americans.” Applied Economics 40(23) :29692985.

Benitez-Silva, Dwyer, D.S., Heiland, F., and Sanderson, W.C. 2007. "Retirement and Social Security Reform Expectations: A Solution to the New Early Retirement Puzzle." Unpublished Working Paper.

Brown, J.R. and Poterba, J.M. 2000. "Joint Life Annuities and Annuity Demand by Married Couples.” Journal of Risk and Insurance 67(4) 527-53.

Brown, J.R., Liebman, J.B., and Pollet, J. 2002. "Estimating Life Tables That Reflect Socioeconomic Differences in Mortality" in: Feldstein, M. and Liebman, J.B. eds., The Distributional Aspects of Social Security and Social Security Reform (Chicago: University of Chicago Press), 447-457.

Brown, J.R. 2002. "Differential Mortality and the Value of Individual Account Retirement Annuities" in: Feldstein, Martin and Jeffrey B. Liebman, eds., The Distributional Aspects of Social Security and Social Security Reform (Chicago: University of Chicago Press), 401-446.

Brown, J.R., Casey, M.D., and Mitchell, O.S. 2007. "Who Values the Social Security Annuity? New Evidence on the Annuity Puzzle." Unpublished Working Paper.

Brown, Jeffrey R. 2007. "Rational and Behavior Perspectives on the Role of Annuities in Retirement Planning.” Working Paper No. 13,537. Cambridge, MA: National Bureau of Economic Research.

Chetty, R. 2003. "A New Method of Estimating Risk Aversion.” Working Paper. 9,988. Cambridge, MA: National Bureau of Economic Research.

Coile, C., Diamond, P., Gruber, J., and Josuten, A. 2002. "Delays in Claiming Social Security Benefits.” Journal of Public Economics 84(3): 357-385.

Coile, C. and Milligan, K. 2006. "How Household Portfolios Evolve After Retirement: The Effect of Aging and Health Shocks." Working Paper 12,391. Cambridge, MA: National Bureau of Economic Research. 
De Nardi, M., French, E., and Jones, J.B. 2006. "Differential Mortality, Uncertain Medical Expenses, and the Saving of Elderly Singles. Working Paper 12,554. Cambridge, MA: National Bureau of Economic Research.

Dushi, I. and Webb, A. 2004. "Household Annuitization Decisions: Simulations and Empirical Analyses." Journal of Pension Economics and Finance 3(2) 109-43.

Hurd, M.D, and McGarry, K. 1995. "Evaluation of the Subjective Probabilities of Survival in the Health and Retirement Study." Journal of Human Resources 30 Supplement S268-292.

Hurd, M.D, and McGarry, K. 2002. "The Predictive Validity of Subjective Probabilities of Survival." Economic Journal 112 October: 965-985.

Hurd, M.D., Smith, J.P., and Zissimopoulos, J.M. 2004. "The Effects of Subjective Survival on Retirement and Social Security Claiming." Journal of Applied Econometrics 19(6):: 761-775.

Gustman, A.L., and Steinmeier, T.L. 2005. "The Social Security Early Entitlement Age in a Structural Model of Retirement and Wealth." Journal of Public Economics 89 (2-3): 441-463.

Mahaney, J.I. and Carlson, P.C. 2007. "Rethinking Social Security Claiming in a 401(k) World." Working Paper 2007-18. Philadelphia, PA: Pension Research Council.

Mitchell, O.S., Poterba, J.M., Warshawsky, M.J., and Brown, J.R. 1999. "New Evidence on the Money's Worth of Individual Annuities" American Economic Review 89(5) : 1299-1318.

Mitchell, O.S. and Utkus, S. 2004. "Lessons from Behavioral Finance for Pension Plan Design" in Mitchell, Olivia S., and Stephen P. Utkus eds. Pension Design and Structure: New Lessons from Behavioral Finance Oxford University Press, Oxford. $(3-42)$.

Muldoon, D. and Kopcke, R.W. 2008. “Are People Claiming Social Security Benefits Later? Issue in Brief 8-7. Chestnut Hill MA: Center for Retirement Research at Boston College.

Munnell, A.H. and Soto, M. 2005. "Why Do Women Claim Social Security Benefits So Early?" Issue in Brief 35. Chestnut Hill MA: Center for Retirement Research at Boston College.

Pang, G. and Warshawsky, M. 2008. "Optimizing the Equity-Bond-Annuity Portfolio in Retirement: The impact of Uncertain Health Expenses." Working Paper 2008-05. Philadelphia, PA: Pension Research Council. 
Sass, S.A., Sun, W, and Webb, A. 2007. "Why Do Married Men Claim Social security Benefits So Early? Ignorance or Caddishness?" Working Paper 2007-17. Chestnut Hill MA: Center for Retirement Research at Boston College.

Turra, C.M. and Mitchell, O.S. 2004. "The impact of Health Status and Out-of-Pocket Medical Expenditures on Annuity Valuation.” Working Paper 2004-086. Ann Arbor, MI: Michigan Retirement Research Center Research.

Warner, J.T. and Pleeter, S. 2001. "The Personal Discount Rate: Evidence from Military Downsizing Programs," American Economic Review, 91(1): 33-53.

Yogo, M. 2008. "Portfolio Choice in Retirement: Health Risk and the Demand for Annuities, Housing, and Risky Assets.” AFA 2009 San Francisco Meetings Paper. 


\section{Table 1: Claim Ages at Which Expected Present Value of Social Security Benefits is Maximized (Husband, Wife)}

Wife's PIA of as a Percent of Husband's PIA

\begin{tabular}{cccc} 
Age Difference & $0-30$ & $30-40$ & $40-100$ \\
\hline \hline 0 & 66,66 & 67,66 & 69,62 \\
1 & 67,66 & 67,66 & 69,62 \\
2 & 68,66 & 68,65 & 69,62 \\
3 & 68,65 & 69,62 & 69,62 \\
4 & 68,64 & 69,62 & 69,62 \\
5 & 68,62 & 69,62 & 69,62 \\
6 & 68,62 & 69,62 & 69,62 \\
Percent of households & 32 & 11 & 47 \\
\hline \hline
\end{tabular}

Note: Age difference equals number of years the husband is older than the wife.

Table 2: Social Security Equivalent Income - Single Men and Women

\begin{tabular}{ccccccr}
\hline \multicolumn{3}{c}{ Single Men } & \multicolumn{5}{c}{ Single Women } \\
Claim Age Money's Worth & CRRA $=2$ & CRRA $=5$ & Money's Worth & CRRA = 2 & CRRA $=5$ \\
62 & 1.000 & 1.113 & 1.158 & 1.029 & 1.150 & 1.190 \\
63 & 1.007 & 1.096 & 1.136 & 1.028 & 1.130 & 1.166 \\
64 & 1.001 & 1.065 & 1.098 & 1.013 & 1.094 & 1.125 \\
65 & 1.003 & 1.043 & 1.070 & 1.006 & 1.068 & 1.094 \\
66 & 1.012 & 1.029 & 1.050 & 1.006 & 1.049 & 1.070 \\
67 & 1.016 & 1.010 & 1.024 & 1.000 & 1.024 & 1.040 \\
68 & 1.029 & 1.000 & 1.007 & 1.002 & 1.008 & 1.019 \\
69 & 1.049 & 1.000 & 1.000 & 1.010 & 1.000 & 1.005 \\
70 & 1.077 & 1.013 & 1.004 & 1.025 & 1.001 & 1.000 \\
\hline
\end{tabular}

Notes: Population mortality for 1946 birth cohort. Rate of interest and time preference both equal three percent. 
Table 3: Social security Equivalent Income - Single Earner Couple

\begin{tabular}{|c|c|c|c|c|c|c|c|c|c|}
\hline Female claim age & 62 & 63 & 64 & 65 & 66 & 67 & 68 & 69 & 70 \\
\hline \multicolumn{10}{|l|}{$\begin{array}{l}\text { Money's worths } \\
\text { Male claim age }\end{array}$} \\
\hline 62 & 1.027 & 1.031 & 1.027 & 1.026 & 1.028 & 1.051 & 1.073 & 1.095 & 1.116 \\
\hline 63 & & 1.035 & 1.031 & 1.030 & 1.032 & 1.055 & 1.078 & 1.099 & 1.121 \\
\hline 64 & & & 1.018 & 1.017 & 1.019 & 1.042 & 1.063 & 1.085 & 1.105 \\
\hline 65 & & & & 1.005 & 1.007 & 1.029 & 1.050 & 1.071 & 1.091 \\
\hline 66 & & & & & 1.000 & 1.021 & 1.042 & 1.063 & 1.083 \\
\hline 67 & & & & & & 1.010 & 1.030 & 1.050 & 1.069 \\
\hline 68 & & & & & & & 1.024 & 1.043 & 1.062 \\
\hline 69 & & & & & & & & 1.041 & 1.060 \\
\hline 70 & & & & & & & & & 1.063 \\
\hline \multicolumn{10}{|l|}{$\mathrm{CRRA}=2$} \\
\hline 62 & 1.078 & 1.079 & 1.070 & 1.066 & 1.063 & 1.084 & 1.104 & 1.124 & 1.143 \\
\hline 63 & & 1.074 & 1.066 & 1.061 & 1.059 & 1.080 & 1.099 & 1.119 & 1.139 \\
\hline 64 & & & 1.044 & 1.039 & 1.038 & 1.057 & 1.076 & 1.095 & 1.114 \\
\hline 65 & & & & 1.018 & 1.017 & 1.035 & 1.054 & 1.072 & 1.090 \\
\hline 66 & & & & & 1.001 & 1.020 & 1.038 & 1.056 & 1.074 \\
\hline 67 & & & & & & 1.000 & 1.018 & 1.035 & 1.052 \\
\hline 68 & & & & & & & 1.004 & 1.021 & 1.038 \\
\hline 69 & & & & & & & & 1.013 & 1.030 \\
\hline 70 & & & & & & & & & 1.028 \\
\hline \multicolumn{10}{|l|}{$C R R A=5$} \\
\hline 62 & 1.111 & 1.110 & 1.102 & 1.096 & 1.094 & 1.113 & 1.132 & 1.151 & 1.170 \\
\hline 63 & & 1.102 & 1.094 & 1.089 & 1.087 & 1.106 & 1.125 & 1.144 & 1.162 \\
\hline 64 & & & 1.067 & 1.062 & 1.060 & 1.079 & 1.097 & 1.115 & 1.133 \\
\hline 65 & & & & 1.035 & 1.033 & 1.051 & 1.068 & 1.085 & 1.102 \\
\hline 66 & & & & & 1.012 & 1.029 & 1.046 & 1.063 & 1.079 \\
\hline 67 & & & & & & 1.004 & 1.020 & 1.035 & 1.051 \\
\hline 68 & & & & & & & 1.000 & 1.015 & 1.031 \\
\hline 69 & & & & & & & & 1.001 & 1.016 \\
\hline 70 & & & & & & & & & 1.008 \\
\hline
\end{tabular}

Notes: See table three. in addition assume 1) One earner couple 2) The husband and the wife are the same age. 
Table 4: Social security Equivalent Income - Age Difference 1-6 Years - CRRA = 5

\begin{tabular}{|c|c|c|c|c|c|c|c|c|c|}
\hline Female claim age & 62 & 63 & 64 & 65 & 66 & 67 & 68 & 69 & 70 \\
\hline Male claim age & & & & & & & & & \\
\hline & & & Bo & the sam & & & & & \\
\hline 62 & 1.111 & 1.110 & 1.102 & 1.096 & 1.094 & 1.113 & 1.132 & 1.151 & 1.170 \\
\hline 63 & & 1.102 & 1.094 & 1.089 & 1.087 & 1.106 & 1.125 & 1.144 & 1.162 \\
\hline 64 & & & 1.067 & 1.062 & 1.060 & 1.079 & 1.097 & 1.115 & 1.133 \\
\hline 65 & & & & 1.035 & 1.033 & 1.051 & 1.068 & 1.085 & 1.102 \\
\hline 66 & & & & & 1.012 & 1.029 & 1.046 & 1.063 & 1.079 \\
\hline 67 & & & & & & 1.004 & 1.020 & 1.035 & 1.051 \\
\hline 68 & & & & & & & 1.000 & 1.015 & 1.031 \\
\hline 69 & & & & & & & & 1.001 & 1.016 \\
\hline 70 & & & & & & & & & 1.008 \\
\hline & & & Wife & ne year $y$ & nnger & & & & \\
\hline 62 & 1.128 & 1.128 & 1.119 & 1.115 & 1.113 & 1.132 & 1.151 & 1.169 & 1.188 \\
\hline 63 & 1.120 & 1.120 & 1.112 & 1.108 & 1.107 & 1.125 & 1.144 & 1.163 & 1.181 \\
\hline 64 & & 1.092 & 1.085 & 1.081 & 1.080 & 1.098 & 1.116 & 1.133 & 1.150 \\
\hline 65 & & & 1.057 & 1.053 & 1.052 & 1.069 & 1.086 & 1.103 & 1.119 \\
\hline 66 & & & & 1.032 & 1.030 & 1.047 & 1.063 & 1.079 & 1.095 \\
\hline 67 & & & & & 1.004 & 1.020 & 1.036 & 1.051 & 1.066 \\
\hline 68 & & & & & & 1.000 & 1.015 & 1.030 & 1.045 \\
\hline 69 & & & & & & & 1.000 & 1.015 & 1.030 \\
\hline 70 & & & & & & & & 1.006 & 1.021 \\
\hline & & & Wife & 0 years & unger & & & & \\
\hline 62 & 1.144 & 1.144 & 1.137 & 1.132 & 1.131 & 1.150 & 1.168 & 1.186 & 1.204 \\
\hline 63 & 1.137 & 1.137 & 1.130 & 1.126 & 1.126 & 1.144 & 1.162 & 1.180 & 1.197 \\
\hline 64 & 1.108 & 1.109 & 1.102 & 1.099 & 1.098 & 1.116 & 1.133 & 1.150 & 1.167 \\
\hline 65 & & 1.080 & 1.074 & 1.071 & 1.070 & 1.087 & 1.103 & 1.119 & 1.135 \\
\hline 66 & & & 1.053 & 1.049 & 1.048 & 1.064 & 1.080 & 1.096 & 1.111 \\
\hline 67 & & & & 1.022 & 1.021 & 1.036 & 1.051 & 1.066 & 1.081 \\
\hline 68 & & & & & 1.000 & 1.015 & 1.030 & 1.044 & 1.059 \\
\hline 69 & & & & & & 1.000 & 1.015 & 1.029 & 1.043 \\
\hline 70 & & & & & & & 1.005 & 1.019 & 1.033 \\
\hline & & & Wife t & ee years & unger & & & & \\
\hline 62 & 1.159 & 1.160 & 1.153 & 1.149 & 1.149 & 1.167 & 1.185 & 1.202 & 1.219 \\
\hline 63 & 1.153 & 1.153 & 1.147 & 1.144 & 1.144 & 1.162 & 1.180 & 1.197 & 1.214 \\
\hline 64 & 1.124 & 1.125 & 1.119 & 1.116 & 1.116 & 1.133 & 1.150 & 1.166 & 1.182 \\
\hline 65 & 1.095 & 1.096 & 1.090 & 1.088 & 1.087 & 1.104 & 1.119 & 1.135 & 1.150 \\
\hline 66 & & 1.074 & 1.069 & 1.066 & 1.065 & 1.081 & 1.096 & 1.111 & 1.126 \\
\hline 67 & & & 1.040 & 1.037 & 1.037 & 1.052 & 1.066 & 1.081 & 1.095 \\
\hline 68 & & & & 1.016 & 1.016 & 1.030 & 1.044 & 1.058 & 1.072 \\
\hline 69 & & & & & 1.000 & 1.014 & 1.028 & 1.042 & 1.055 \\
\hline 70 & & & & & & 1.004 & 1.018 & 1.032 & 1.045 \\
\hline & & & Wife & ur years & unger & & & & \\
\hline 62 & 1.170 & 1.170 & 1.165 & 1.162 & 1.162 & 1.179 & 1.196 & 1.213 & 1.230 \\
\hline 63 & 1.164 & 1.165 & 1.159 & 1.157 & 1.157 & 1.175 & 1.192 & 1.208 & 1.224 \\
\hline 64 & 1.135 & 1.136 & 1.131 & 1.129 & 1.130 & 1.146 & 1.162 & 1.178 & 1.193 \\
\hline 65 & 1.106 & 1.107 & 1.102 & 1.100 & 1.100 & 1.116 & 1.131 & 1.146 & 1.161 \\
\hline 66 & 1.085 & 1.086 & 1.081 & 1.078 & 1.078 & 1.093 & 1.108 & 1.122 & 1.137 \\
\hline 67 & & 1.057 & 1.051 & 1.049 & 1.049 & 1.063 & 1.077 & 1.091 & 1.104 \\
\hline 68 & & & 1.030 & 1.027 & 1.027 & 1.040 & 1.054 & 1.067 & 1.080 \\
\hline 69 & & & & 1.011 & 1.010 & 1.024 & 1.038 & 1.051 & 1.063 \\
\hline 70 & & & & & 1.000 & 1.014 & 1.027 & 1.040 & 1.053 \\
\hline & & & Wife & ve years & unger & & & & \\
\hline 62 & 1.168 & 1.170 & 1.164 & 1.162 & 1.163 & 1.180 & 1.196 & 1.212 & 1.228 \\
\hline 63 & 1.163 & 1.165 & 1.160 & 1.159 & 1.159 & 1.176 & 1.192 & 1.208 & 1.223 \\
\hline 64 & 1.135 & 1.137 & 1.132 & 1.131 & 1.132 & 1.147 & 1.163 & 1.178 & 1.192 \\
\hline 65 & 1.107 & 1.108 & 1.103 & 1.102 & 1.102 & 1.117 & 1.132 & 1.146 & 1.160 \\
\hline 66 & 1.086 & 1.086 & 1.082 & 1.080 & 1.081 & 1.095 & 1.109 & 1.123 & 1.136 \\
\hline 67 & 1.056 & 1.057 & 1.052 & 1.050 & 1.051 & 1.064 & 1.077 & 1.090 & 1.103 \\
\hline 68 & & 1.034 & 1.030 & 1.028 & 1.028 & 1.041 & 1.054 & 1.066 & 1.078 \\
\hline 69 & & & 1.013 & 1.011 & 1.011 & 1.024 & 1.036 & 1.049 & 1.060 \\
\hline 70 & & & & 1.000 & 1.000 & 1.013 & 1.025 & 1.037 & 1.049 \\
\hline & & & Wife & $x$ years & inger & & & & \\
\hline 62 & 1.167 & 1.168 & 1.164 & 1.163 & 1.163 & 1.179 & 1.195 & 1.210 & 1.225 \\
\hline 63 & 1.163 & 1.164 & 1.161 & 1.159 & 1.161 & 1.176 & 1.192 & 1.207 & 1.221 \\
\hline 64 & 1.135 & 1.136 & 1.133 & 1.132 & 1.133 & 1.148 & 1.163 & 1.177 & 1.191 \\
\hline 65 & 1.107 & 1.108 & 1.104 & 1.103 & 1.104 & 1.118 & 1.132 & 1.145 & 1.158 \\
\hline 66 & 1.086 & 1.087 & 1.083 & 1.082 & 1.083 & 1.096 & 1.110 & 1.122 & 1.134 \\
\hline 67 & 1.056 & 1.057 & 1.053 & 1.051 & 1.052 & 1.065 & 1.077 & 1.089 & 1.101 \\
\hline 68 & 1.033 & 1.034 & 1.030 & 1.028 & 1.029 & 1.041 & 1.053 & 1.065 & 1.076 \\
\hline 69 & & 1.017 & 1.013 & 1.011 & 1.012 & 1.024 & 1.035 & 1.047 & 1.058 \\
\hline 70 & & & 1.002 & 1.000 & 1.000 & 1.012 & 1.024 & 1.035 & 1.046 \\
\hline
\end{tabular}

Notes: See table four. Except husband has population mortality for the 1946 birth cohort. Wife has population mortality for the

1947-1952 birth cohort, as appropriate. The coefficient of risk aversion equals five. 
Table 5: Social security Equivalent Income - Two Earner Couples - CRRA = 5

$\begin{array}{llllllllll}\text { Female claim age } & 62 & 63 & 64 & 65 & 66 & 67 & 68 & 69 & 70\end{array}$

Male claim age

The wife's PIA is $0 \%$ of the husband's PIA

\begin{tabular}{|c|c|c|c|c|c|c|c|c|c|}
\hline 62 & 1.111 & 1.110 & 1.102 & 1.096 & 1.094 & 1.113 & 1.132 & 1.151 & 1.170 \\
\hline 63 & & 1.102 & 1.094 & 1.089 & 1.087 & 1.106 & 1.125 & 1.144 & 1.162 \\
\hline 64 & & & 1.067 & 1.062 & 1.060 & 1.079 & 1.097 & 1.115 & 1.133 \\
\hline 65 & & & & 1.035 & 1.033 & 1.051 & 1.068 & 1.085 & 1.102 \\
\hline 66 & & & & & 1.012 & 1.029 & 1.046 & 1.063 & 1.079 \\
\hline 67 & & & & & & 1.004 & 1.020 & 1.035 & 1.051 \\
\hline 68 & & & & & & & 1.000 & 1.015 & 1.031 \\
\hline 69 & & & & & & & & 1.001 & 1.016 \\
\hline 70 & & & & & & & & & 1.008 \\
\hline
\end{tabular}

The wife's PIA is $25 \%$ of the husband's PIA

\begin{tabular}{|l|r|r|r|r|r|r|r|r|r|}
\hline 62 & 1.137 & 1.136 & 1.127 & 1.122 & 1.119 & 1.139 & 1.159 & 1.178 & 1.197 \\
\hline 63 & 1.136 & 1.128 & 1.119 & 1.114 & 1.112 & 1.132 & 1.152 & 1.171 & 1.190 \\
\hline 64 & 1.115 & 1.108 & 1.092 & 1.087 & 1.086 & 1.104 & 1.123 & 1.141 & 1.160 \\
\hline 65 & 1.094 & 1.087 & 1.073 & 1.060 & 1.058 & 1.076 & 1.094 & 1.111 & 1.129 \\
\hline 66 & 1.078 & 1.072 & 1.058 & 1.047 & 1.037 & 1.054 & 1.071 & 1.088 & 1.105 \\
\hline 67 & 1.057 & 1.052 & 1.039 & 1.028 & 1.019 & 1.028 & 1.044 & 1.060 & 1.076 \\
\hline 68 & 1.043 & 1.038 & 1.026 & 1.016 & 1.008 & 1.015 & 1.024 & 1.040 & 1.056 \\
\hline 69 & 1.034 & 1.029 & 1.018 & 1.009 & 1.001 & 1.008 & 1.017 & 1.026 & 1.041 \\
\hline 70 & 1.031 & 1.026 & 1.016 & 1.007 & 1.000 & 1.007 & 1.014 & 1.023 & 1.033 \\
\hline & & The wife's PIA is 50\% of the husband's PIA & & \\
\hline 62 & 1.154 & 1.154 & 1.152 & 1.152 & 1.154 & 1.156 & 1.160 & 1.166 & 1.175 \\
\hline 63 & 1.146 & 1.147 & 1.145 & 1.145 & 1.148 & 1.149 & 1.154 & 1.160 & 1.169 \\
\hline 64 & 1.118 & 1.119 & 1.117 & 1.117 & 1.120 & 1.122 & 1.126 & 1.132 & 1.141 \\
\hline 65 & 1.090 & 1.091 & 1.089 & 1.089 & 1.092 & 1.093 & 1.097 & 1.103 & 1.111 \\
\hline 66 & 1.069 & 1.070 & 1.067 & 1.067 & 1.070 & 1.071 & 1.075 & 1.080 & 1.088 \\
\hline 67 & 1.043 & 1.044 & 1.042 & 1.042 & 1.043 & 1.045 & 1.048 & 1.053 & 1.061 \\
\hline 68 & 1.024 & 1.025 & 1.022 & 1.022 & 1.024 & 1.025 & 1.028 & 1.033 & 1.040 \\
\hline 69 & 1.010 & 1.011 & 1.009 & 1.009 & 1.010 & 1.011 & 1.014 & 1.019 & 1.026 \\
\hline 70 & 1.002 & 1.003 & 1.000 & 1.000 & 1.002 & 1.003 & 1.006 & 1.010 & 1.017 \\
\hline
\end{tabular}

Notes: See table four. Except the wife has her own PIA as a percentage of her husband's PIA. The coefficient of risk aversion equals five. 
Table 6: Social security Equivalent Income - Impatient and High/Low Mortality Couples - CRRA = 5

$\begin{array}{lllllllllll}\text { Female claim age } & 62 & 63 & 64 & 65 & 66 & 67 & 68 & 69 & 70\end{array}$

Male claim age

Three percent arte of time preference, population avearge mortality

\begin{tabular}{|l|l|r|r|r|r|r|r|r|r|}
\hline 62 & 1.111 & 1.110 & 1.102 & 1.096 & 1.094 & 1.113 & 1.132 & 1.151 & 1.170 \\
\hline 63 & & 1.102 & 1.094 & 1.089 & 1.087 & 1.106 & 1.125 & 1.144 & 1.162 \\
\hline 64 & & & 1.067 & 1.062 & 1.060 & 1.079 & 1.097 & 1.115 & 1.133 \\
\hline 65 & & & & 1.035 & 1.033 & 1.051 & 1.068 & 1.085 & 1.102 \\
\hline 66 & & & & & 1.012 & 1.029 & 1.046 & 1.063 & 1.079 \\
\hline 67 & & & & & & 1.004 & 1.020 & 1.035 & 1.051 \\
\hline 68 & & & & & & & 1.000 & 1.015 & 1.031 \\
\hline 69 & & & & & & & & 1.001 & 1.016 \\
\hline 70 & & & & & & & & & 1.008 \\
\hline
\end{tabular}

Five percent rate of time preference

\begin{tabular}{|c|c|c|c|c|c|c|c|c|c|}
\hline 62 & 1.105 & 1.104 & 1.095 & 1.090 & 1.088 & 1.107 & 1.127 & 1.146 & 1.165 \\
\hline 63 & & 1.096 & 1.088 & 1.083 & 1.081 & 1.101 & 1.120 & 1.139 & 1.157 \\
\hline 64 & & & 1.062 & 1.057 & 1.055 & 1.074 & 1.092 & 1.111 & 1.128 \\
\hline 65 & & & & 1.031 & 1.029 & 1.047 & 1.065 & 1.082 & 1.099 \\
\hline 66 & & & & & 1.009 & 1.026 & 1.044 & 1.060 & 1.077 \\
\hline 67 & & & & & & 1.002 & 1.018 & 1.034 & 1.051 \\
\hline 68 & & & & & & & 1.000 & 1.016 & 1.032 \\
\hline 69 & & & & & & & & 1.004 & 1.019 \\
\hline 70 & & & & & & & & & 1.014 \\
\hline \multicolumn{10}{|c|}{ Ten percent rate of time preference } \\
\hline 62 & 1.089 & 1.088 & 1.080 & 1.074 & 1.073 & 1.092 & 1.112 & 1.132 & 1.151 \\
\hline 63 & & 1.081 & 1.073 & 1.068 & 1.067 & 1.087 & 1.107 & 1.126 & 1.145 \\
\hline 64 & & & 1.049 & 1.045 & 1.043 & 1.062 & 1.081 & 1.100 & 1.119 \\
\hline 65 & & & & 1.021 & 1.020 & 1.038 & 1.057 & 1.075 & 1.093 \\
\hline 66 & & & & & 1.003 & 1.021 & 1.039 & 1.057 & 1.075 \\
\hline 67 & & & & & & 1.000 & 1.018 & 1.036 & 1.053 \\
\hline 68 & & & & & & & 1.004 & 1.022 & 1.040 \\
\hline 69 & & & & & & & & 1.016 & 1.034 \\
\hline 70 & & & & & & & & & 1.039 \\
\hline \multicolumn{10}{|c|}{ Black less than high school } \\
\hline 62 & 1.098 & 1.100 & 1.095 & 1.092 & 1.093 & 1.112 & 1.131 & 1.149 & 1.166 \\
\hline 63 & & 1.094 & 1.089 & 1.087 & 1.088 & 1.107 & 1.126 & 1.144 & 1.161 \\
\hline 64 & & & 1.062 & 1.061 & 1.062 & 1.080 & 1.098 & 1.115 & 1.131 \\
\hline 65 & & & & 1.033 & 1.034 & 1.051 & 1.068 & 1.084 & 1.100 \\
\hline 66 & & & & & 1.012 & 1.029 & 1.045 & 1.061 & 1.077 \\
\hline 67 & & & & & & 1.003 & 1.019 & 1.034 & 1.049 \\
\hline 68 & & & & & & & 1.000 & 1.015 & 1.029 \\
\hline 69 & & & & & & & & 1.002 & 1.016 \\
\hline 70 & & & & & & & & & 1.009 \\
\hline
\end{tabular}

White College Educated

\begin{tabular}{|l|l|l|l|l|r|r|r|r|r|}
\hline 62 & 1.115 & 1.114 & 1.104 & 1.097 & 1.094 & 1.113 & 1.132 & 1.152 & 1.171 \\
\hline 63 & & 1.105 & 1.095 & 1.089 & 1.086 & 1.105 & 1.124 & 1.143 & 1.162 \\
\hline 64 & & & 1.068 & 1.062 & 1.059 & 1.078 & 1.096 & 1.114 & 1.132 \\
\hline 65 & & & & 1.036 & 1.033 & 1.051 & 1.068 & 1.085 & 1.103 \\
\hline 66 & & & & & 1.012 & 1.029 & 1.046 & 1.063 & 1.080 \\
\hline 67 & & & & & & 1.003 & 1.020 & 1.036 & 1.052 \\
\hline 68 & & & & & & & 1.000 & 1.016 & 1.031 \\
\hline 69 & & & & & & & & 1.001 & 1.017 \\
\hline 70 & & & & & & & & & 1.008 \\
\hline
\end{tabular}

Notes: See table four. Except time perference and mortality changed as appropriate. Coefficient of risk aversion equals five. 


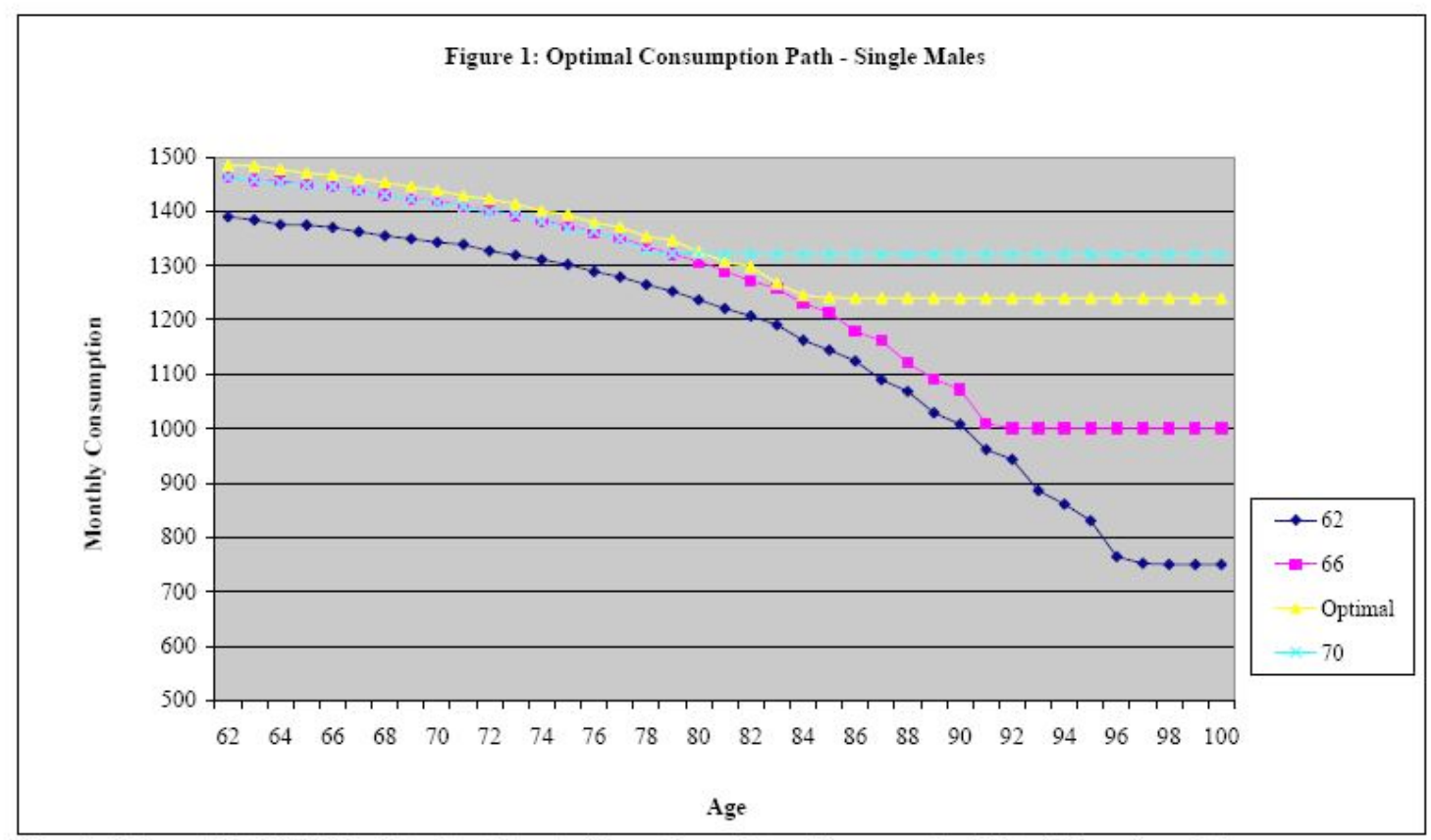

Notes: Population mortality for 1946 birth cohort. Rate of interest and time preference both equal three percent. Coefficient of risk aversion equals five.

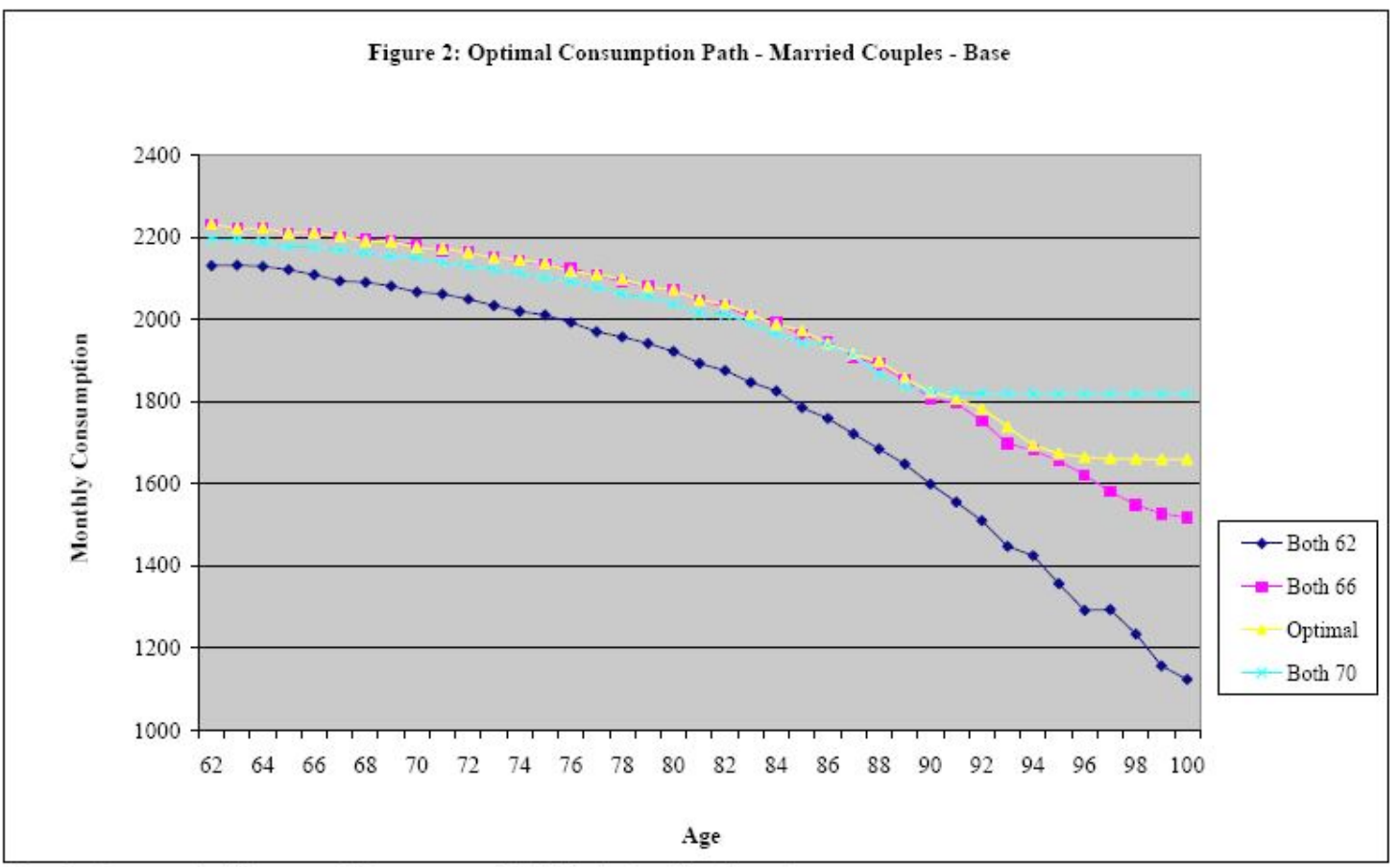

Notes: See figure one, in addition assume 1) One eamer couple 2) The husband and the wife are the same age. 


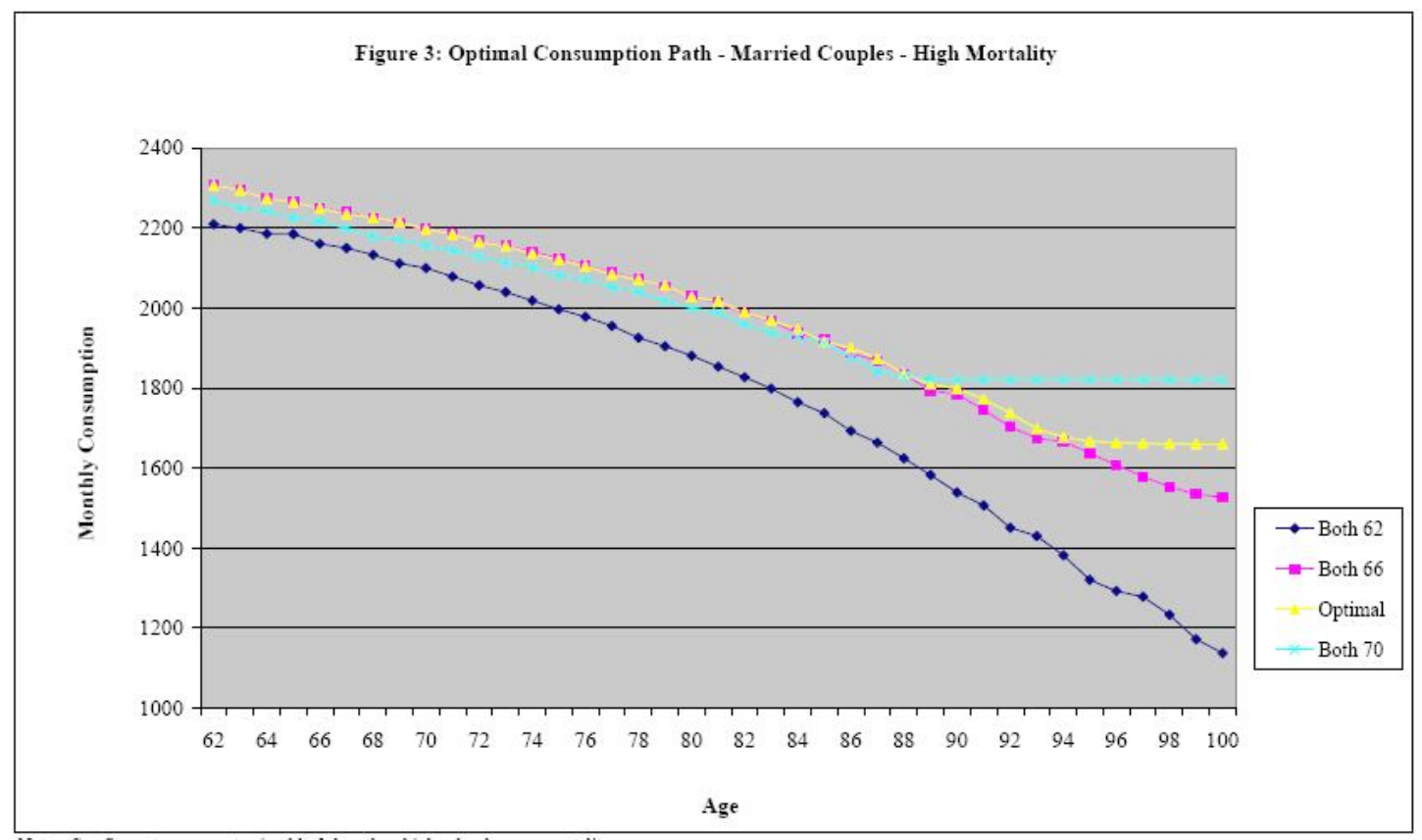

Notes: See figure two, except using black less than high school group mortality 


\section{RECENT WORKING PAPERS FROM THE}

\section{CENTER FOR RETIREMENT RESEARCH AT BOSTON COLLEGE}

Health Care, Health Insurance, and the Relative Income of the Elderly and Nonelderly

Gary Burtless and Pavel Svaton, March 2009

Do Health Problems Reduce Consumption at Older Ages?

Barbara A. Butrica, Richard W. Johnson, and Gordon B.T. Mermin, March 2009

Financial Hardship Before and After Social Security's Early Eligibility Age

Richard W. Johnson and Gordon B.T. Mermin, March 2009

Rising Tides and Retirement: The Aggregate and Distributional Effects of Differential Wage Growth on Social Security

Melissa M. Favreault, February 2009

Accounting for the Heterogeneity in Retirement Wealth

Fang Yang, January 2009

Labor Supply Elasticity and Social Security Reform

Selahattin Imrohorolu and Sagiri Kitao, January 2009

Evaluating Micro-Survey Estimates of Wealth and Saving

Barry P. Bosworth and Rosanna Smart, January 2009

Portfolio Choice in Retirement: Health Risk and the Demand for Annuities, Housing, and Risky Assets

Motohiro Yogo, January 2009

The Disappearing Defined Benefit Pension and its Potential Impact on the Retirement Incomes of Boomers

Barbara A. Butrica, Howard M. Iams, Karen E. Smith, and Eric J. Toder, January 2009

Retirement and Social Security: A Time Series Approach

Brendan Cushing-Daniels and C. Eugene Steuerle, January 2009

Economic Restructuring and Retirement in Urban China

John Giles, January 2009

All working papers are available on the Center for Retirement Research website

(http://www.bc.edu/crr) and can be requested by e-mail (crr@bc.edu) or phone (617-552-1762). 